\title{
THE IMPORTANCE OF INCUBATION PROCESSES FROM THE PERSPECTIVE OF INCUBATED AND GRADUATED COMPANIES
}

\author{
Denise Isabel Rizzi \\ Jocimar Vazocha Wescinski \\ Odilon Poli \\ Claudio Alcides Jacoski \\ Universidade Comunitária da Região de Chapecó, Santa Catarina, Brazil
}

\begin{abstract}
This study seeks to analyze the importance of the incubation process for the viability and development of micro and small enterprises based on the perspective of incubated and/or graduated companies, in a technological incubator linked to a Community College in Santa Catarina. With respect to its objectives, this is a study of a descriptive nature with a qualitative approach. The data collection occurred through the application of a questionnaire. Through this study, it was possible to observe that the incubator is/was of great importance in the formation and implementation of the companies, providing greater viability and continuation for these companies on the market.
\end{abstract}

Keywords: Technological Incubator, Entrepreneurial University, Innovation, Incubation, Knowledge Transfer.

Manuscript first received/Recebido em: 2017/Jul/18 Manuscript accepted/Aprovado em: 2017/Aug/29

Address for correspondence / Endereço para correspondência:

Denise Isabel Rizzi , UNOCHAPECÓ, Santa Catarina, Brazil. E-mail: deniserizzi@ unochapeco.edu.br

Jocimar Vazocha Wescinski, UNOCHAPECÓ, Santa Catarina, Brazil. E-mail: joci@ unochapeco.edu.br

Odilon Poli , UNOCHAPECÓ, Santa Catarina, Brazil. E-mail: odilon@ unochapeco.edu.br

Claudio Alcides Jacoski , UNOCHAPECÓ, Santa Catarina, Brazil. E-mail: claudio@ unochapeco.edu.br

Published by/ Publicado por: TECSI FEA USP - 2017 All rights reserved. 


\section{INTRODUCTION}

The current developmental dynamics in the world economy are strongly influenced by the consolidation of a new technical-economic paradigm, where the globalization of the economy leads the productive sector to increase its effort in the quest for competitiveness. This factor has been an essential element for the modernization of the national productive park with the purpose of expanding its participation in the international trade of goods and services. Coupled to this concept, technological innovation is another influential factor in the current economic development scenario, which is understood here as the transformation of knowledge into products, processes and services that may be placed on the market - which has become increasingly important for the socioeconomic development of countries and regions. Carefully formulated measures are therefore needed to encourage scientific and technological activities in alignment with the demands of the productive sector to expand the industrial structures with conditions to operate in a globalized market (Brazil, 2002).

Innovation and technological progress are the result of a complex set of relationships between actors, producing, distributing and applying knowledge from different fields (Meyer et al., 2014). The interaction between universities and the productive sector is essential for the innovation process, merging knowledge transfer with useful techniques for technological development in industry (Benedetti \& Torkomian, 2011).

The Triple Helix Model described by Etzkowitz (2009) suggests that the key to innovation and growth in a knowledge-based economy lies in the interaction between universities, industry and the government. Physically, this model can be applied to economies through venture capital firms, science and technology parks and business incubators.

Business incubators are institutions that assist in the development of starting or operating micro and small enterprises seeking to modernize their activities so as to transform ideas into products, processes and services. They offer technical, management and additional training support to the entrepreneur. The incubator also facilitates and streamlines the technological innovation process in small businesses. The companies looking for Incubators receive not only management, administrative and marketing support, but also technical support for the development of their product. As such, the venture can be accompanied with expert advice from the planning phase until the consolidation of its activities (Sebrae, 2015).

The growing business incubator movement in Brazil in recent years points to the need to understand and improve incentive mechanism in order to create the necessary and favorable conditions to support the technology-based enterprises involved in such mechanisms as incubators and technology parks and centers (Stainsack, 2003).

In this sense, the objective of this study is to analyze the importance of the incubation process in making the development of incubated and/or graduated micro and small enterprises viable.

Studies using this approach are justified because innovation lies at the heart of current competitive strategies, and in this process, the role of technological incubators is to bring companies, public authorities and universities together for the promotion of the innovation process (Anprotec, 2016). Studying incubators and highlighting their importance to society is 
important, since the development of entrepreneurship and innovation can be driven with the support of incubators so as to make it easier to cope with the uncertainties of entrepreneurial action, both those arising from the external environment as those inherent to entrepreneurship.

In addition to this introduction, this text is organized into four sections. Firstly, a literature review is presented regarding the interaction between university and company, the entrepreneurial university concept, the transfer of technological knowledge and the incubation of enterprises. Next, the methodological procedures used in the development of the study are presented, followed by the presentation of the research results. Finally, the conclusions and recommendations of the study are laid out based on the results, in addition to the main references used to provide theoretical support to this study.

\section{THEORETICAL FRAMEWORK}

In this section, some of the key concepts used for understanding and discussing the importance of incubation for the development and consolidation of new ventures with a focus on innovation are discussed, with emphasis on the university-company relationship and the knowledge transfer process.

\subsection{The University-Company Interaction}

The growing importance assigned in recent years to education, information and the ability to generate and use knowledge and innovation, is related to the increasing interaction between universities and companies in promoting innovation. Aguiar (2000) argues that the interaction between university and company is an indispensable precondition for the materialization of technological progress and an improved socioeconomic use of the produced scientific and technological knowledge.

Following the objective of linking education, research and economic \& social development, universities are turning to promoting innovation and seeking interactions with the productive sector to improve the efficiency of these results. According to Silva (2010), the growing importance attributed to education, information and the ability to generate and use knowledge as strategic resources for the development of innovation, in addition to the need for synergies between the various segments and institutions, are the foundations that support the interaction between universities and companies.

The interaction between university and company is a form of scientific and technological cooperation, which contributes in a decisive, even if sometimes hardly visible, manner to innovation development. To this end, mutual knowledge, the exchange of experiences, the implementation of joint activities, strategic alliances, the coordination of policies, and the dissemination and transfer of knowledge and technologies are crucial (da Gama Mota, 2013).

The interaction between university and company has therefore become a vehicle for interactive and innovative learning. It should be noted, however, that universities and companies are guided by their own and distinct values, different cycles and times, and their own goals and motives. Nevertheless, where these intersect, a complementarity is needed so as to benefit social interests (Marcovitch, 1999; Levy, Roux \& Wolf, 2000; Soria, 2011). 
In the quest for greater competitiveness through the inclusion of innovations in their products and services, companies have come to see the need for more efficiency in the use of scientific and technological resources. As such, the interest arose to collaborate with competitors and public and private institutions, including universities, to share experiences and knowledge with a focus on innovation (Maya, 2008).

It is from this perspective that the Triple Helix Model arises, emphasizing the interaction between universities and companies and creating a more favorable environment for the organization and cooperation between university-company-government. Brisolla et al, (1997) emphasizes that the greater approximation between universities and the business sector doesn't imply a withdrawal of the State. On the contrary, the triple helix is characterized by the intensification of relations between the Government, the University and the Company, creating an environment conducive to innovation and the generation and spread of knowledge in order to develop society (Brisolla, et al.,1997; Etzkowitz, 2009).

Currently, therefore, the appreciation of science \& technology and research \& development activities for nation states and companies has become perfectly clear. The technological innovation arising from the interaction between university and company emerges as the decisive variable to achieve and sustain the competitive advantages of a country's companies, sectors and economic spaces (da Gama Mota, 2013; Etzkowitz, 2009).

\subsection{The Entrepreneurial University}

In the mid-19th century, important changes began taking place in universities with the first academic revolution, resulting in a transition from an educational institution to a research institution. In the 20th century, on the other hand, the second academic revolution took place, and universities were now also tasked with promoting economic and social development. In this new scenario, universities take on a new, fundamental role in society, becoming crucial actors for the triggering of innovation, job creation, economic growth and sustainability (Etzkowitz, 2009).

From a developmental and entrepreneurial perspective, the university is seen as a natural incubator, providing a support structure for teachers and students so they may start their endeavors. In addition, an explicitly entrepreneurial university takes the lead by putting knowledge to work and by expanding its contribution in the creation of academic knowledge. The development of an entrepreneurial culture encourages the faculty staff to observe the results of their research in order to verify both its commercial and intellectual potential. This way, academic entrepreneurship is transformed in parallel with the transition to a knowledgebased economy (Etzkowitz, 2009).

The entrepreneurial university can therefore be defined as an active institution, which makes changes to its structure and to the way it reacts to internal and external demands (Clark, 2004). To be in tune with the current competitive scenario and based on the adjustments they are forced to implement to thrive and better meet their mission, universities have become entrepreneurial and creative, managing their tasks more effectively as a business in order to satisfy their customers (Rodrigues \& Tontini, 1997).

The university itself is an environment for potential innovation. To develop this quality, the importance of institutionalizing this new vision of the University is emphasized, in addition 
to the institutional mechanisms to enable it, which are not only restricted to the desire of some leaders. The definition of institutional policies and the development of innovation environments are important to create the conditions for the development of a climate geared to innovation and entrepreneurship. A clear and shared strategic vision in the institution is the starting point for the transformation and renewal process of the academic environment (Audy \& Morosini, 2008).

From this perspective, the pillars of an entrepreneurial university, according to Etzkowitz (2009), are: an academic leadership capable of formulating and implementing a strategic vision; legal control over academic resources, including physical properties, such as the university buildings, and the intellectual property resulting from the research; an organizational capacity to transfer technology through patenting, licensing and incubation; and an entrepreneurial ethos among administrators, faculty and students.

With this, the University starts to act in a complex context where new interfaces with society are required in order to capture its needs and demands. Flexibility and the ability to adapt are important aspects in this balance between demand and the capacity to respond, and it is fundamental to preserve the academic values expressed in the teaching and research activities developed by the university.

As such, the transfer of knowledge generated at the university becomes a strategic issue, since it is a potential source of funding for university research and a political tool for economic development (Soria, 2011; Geuna \& Muscio, 2009).

\subsection{Technological Knowledge Transfer}

In recent years, several researchers have developed studies demonstrating the significant influence of knowledge transfers on the innovative capacity of organizations. Organizations are continually looking for opportunities to innovate beyond their organizational boundaries, involving themselves, therefore, in inter-organizational collaborations. This way, the sources of innovation are not found exclusively within companies, but also at the interfaces between companies, universities, research laboratories, suppliers and customers (Mussi et al., 2013).

Innovation has been characterized as an interactive process in which knowledge sharing between and within companies and in collaboration with other entities is of great importance. In this vein, universities and research institutes are also seen as relevant sources of production and knowledge transfer. Through their traditional functions, such as education and basic research, these agents create and renew a country's knowledge inventory, in addition to playing a crucial role in technological development, both through the formation and training of engineers and industrial scientists and as sources of research and techniques for innovative progress in industry. (Castro, Teixeira \& Lima, 2014).

The use of the knowledge generated in universities is a rich source of information and qualification for the development of new technologies, and technology transfers between the university and the productive sector are an alternative and complementary path for companies to reach a superior technological level (Garnica \& Torkomian, 2009). 
Because of the importance of information sharing and the role of universities and research institutes in this context, many studies have explored the various forms of knowledge transfer from these institutions to businesses, which include formal cooperation, the recruitment of students, networking, seminars and congresses, among others (Joseph \& Abraham, 2009).

Based on a study by Bonacorsi and Piccaluga (1994), Soria (2011) highlights that the main forms of technological knowledge transfer in the interaction between companies and universities include: informal personal relationships (individual consultation; integration forums, workshops, among others); formal personal relationships (personnel exchanges, specialization courses at universities); institutional ties (partnership relationship via a third party, trade associations, applied research institutes); formal umbrella agreements (without specific goals, industry sponsorship for R\&D in university departments, private donations for research) and the creation of structures for interaction (technology parks, business incubators, research consortia).

\subsection{Business Incubators}

Business incubators are a global phenomenon, arising primarily in developed countries, which identified a developmental potential in this modality of support to emerging companies, especially through its potential of transforming technology into innovative processes. In Brazil, the government has taken cautious action toward the promotion of a favorable environment for the development of business incubators (D'Afonsêca, 2007). According to data analyzed by the ANPROTEC, there were 384 (three hundred and eighty-four) incubators operating in Brazil in 2011.

The structure of the incubators has been improving since the 1970s when universities, local governments and financial institutions in the United States and Western Europe came together to promote the industrialization process in decadent or poorly developed regions. In this sense, this type of organization tends to contribute positively to the maturation process of business startups, including through the possibility of offering guidance on the internal controls needed to improve the management of new ventures (Dornelas, 2002).

One of the main regulatory bodies of technological incubators in Brazil is the Ministry of Science, Technology, Innovation and Communications (MCTI), which defines strategic actions geared to promoting innovation to increase the competitiveness and international integration of Brazilian companies. These actions include: encouraging the creation of new technology-based companies, especially through the incubation and the development of venture capital; and supporting the spread of the entrepreneurial culture in the education system (Brazil, 2002).

One of the main purposes of a business incubator for technology-based companies is to promote the creation and development of micro and small technology-based companies through the intensive use of scientific and technological knowledge and information. To achieve this objective, the region where the incubator is installed must have an adequate higher education, technical and research structure, enabling innovation and the transfer of technology so the products and services of the incubated companies can be competitive in the global market (Gevaerd, 2005). 
The business incubation process in Brazil is divided into: 1) technology-based incubators; 2) traditional incubators; 3) mixed incubators; 4) social incubators; and 5) incubators of cooperatives. The technology-based incubators deal with companies in which technology represents a significant portion of the value added to the products, processes or services. The traditional incubators, in turn, cover companies of different sectors of the economy that want to add value to their products, processes or services, but which use widelydiffused technologies. The mixed incubators are those containing both technology-based ventures and traditional sectors of the economy. Finally, the social and cooperative incubators bring together ventures from social projects and associations (Anprotec, 2016). The incubator of this study is characterized as a mixed incubator.

Incubators are seen as a flexible, encouraging and facilitating environment for the emergence, growth and development of new ventures, or for the development of alreadyexisting enterprises, whose expected results should ensure, in a certain time frame, the autonomy and sustainability of the businesses. Incubators are also considered to be laboratories and storehouses of innovations (Aranha, 2000).

According to Silva and Andrade Junior (2012), it should be emphasized that business incubators offer benefits not only to the incubated company, but also to other agents involved in this process. For the incubated companies, for example, synergies are created between the company and the client and access is given to technological capital, among other advantages. For the government, the incubator helps overcome market failures; generates jobs, income and taxes; and becomes a demonstration of the political commitment with small businesses. For the research institutes and universities, the incubator helps strengthen the interactions between universities and industry and provides opportunities for students and teachers to employ their skills. For the local community, it develops self-esteem, the entrepreneurial culture and promotes an increase in income. And for the international community, it creates opportunities for trade, technology transfers and experiences through associations and alliances.

The systemic role played by incubators, therefore, attracts the attention of economic and social players as stakeholders in the incubated ventures, such as universities, research centers, entrepreneurs, financial agents, venture capitalists, government authorities and development agencies, among others. Linked to this interest, the incubators generate an environment that brings together the facilities sought by the entrepreneur to put an innovative venture into practice: infrastructure, management, human resources and financing (D'Afonsêca, 2007).

\section{METHODOLOGY}

This study can be classified as descriptive when considering its objectives, because according to Gil (2010), descriptive studies seek to describe the characteristics of a population, phenomenon or experience. A case study was chosen as research procedure, with Gil (2010) arguing that the case study consists of a thorough and comprehensive study on one or a few subjects, in a manner that allows for their broad and detailed understanding.

As to the approach, this study is classified as qualitative, since its objective is related to the "gathering of data on the motivations of a group, understanding and interpreting certain behaviors, beliefs and expectations of the individuals of a population" (Turato, 2003: 509). 
The environment in which this study occurs is a technological incubator called INCTECh linked to a community university in Santa Catarina, located in the main city of the western region of the State of Santa Catarina (Chapecó), and which for the remainder of this text will be called "the Incubator".

The incubator started its activities in 2003 as a program for the promotion of startups to support and create new technology-based businesses with environmental responsibility in order to promote local economic development, in addition to providing a mechanism for encouraging and supporting the development of research and technology transfer projects with a focus on innovation. It also has the vision to be a reference in the development and consolidation of companies (Unochapecó, 2016).

The data collection occurred through the application of a questionnaire during the month of September 2016. The population of the study involved 22 incubated or graduated companies linked to the incubator, of with 14 companies responded and, as such, made up the study sample.

The questionnaire consisted of 21 questions and had the format of open, closed and multiple-choice questions. It was developed by the researchers based on a theoretical framework developed through preliminary surveys with entrepreneurs for the definition of some parameters related to the companies under study. The issues raised by the questionnaire for the incubated and graduated companies were related to their experience, time of operation, vision regarding the services offered, created and answered expectations, the difficulties and advances that occurred during the incubation process, and suggestions for improvement of the services offered.

\section{DATA PRESENTATION AND ANALYSIS}

The data presentation and analysis is organized in two parts. First a contextualization of the incubator under study is presented. Next, the perception of the incubated companies is analyzed, identifying the relevance and the impact of the incubator on the development of their businesses.

\subsection{History of the Incubator}

The Incubator serving as environment for this study seeks to develop exchange actions between the agents of the Triple Helix in order to facilitate the access of businesses to information related to technology, business opportunities, credit, markets, legislation, research and technical publications; promote the strengthening and development of companies through its business management, focusing on levels of performance and competitiveness; ensure conditions of efficiency in the production and marketing of their products and services through the creation, structuring, restructuring, transfer and incorporation of new technologies; and contribute to an increase in the competitiveness of the incubated firms through performance improvement initiatives in the identification of new business opportunities.

The activities for the deployment of the Incubator began being developed in mid-2001 through a term of commitment and partnership between the university and the SEBRAE, which resulted in an economic-financial feasibility study for the deployment of an incubator in the 
region of Chapecó. The study was carried out in 2002 by the incubator GENESS, with favorable results.

As such, the Statement of Commitment for the deployment of the incubator in the city of Chapecó was signed in 2003 by the following partners at the time: Commercial Industrial Trade Association of Chapecó (Associação Comercial Industrial de Chapecó- ACIC), Chamber of Shopkeepers of Chapecó (Câmara dos Dirigentes Legistas de Chapecó - CDL), Commerce Trade Union (Sindicato de Comércio - SICOM), Brazilian Service of Support to Micro and Small Businesses (Serviço Brasileiro de Apoio às Micro e Pequenas Empresas SEBRAE) and the University, resulting in the establishment, in the same year, of the technological incubator through the creation of its statute and its installation in the building of the Executive Center of the Corporate System of Chapecó (Centro Executivo Do Sistema Empresarial de Chapecó - CESEC), starting its activities.

In 2004, the incubator released its first notice for the selection of companies and then incubated its first ventures, namely Free Time, E-ComBr and Voss Comunicação. In 2007, as a result of the developed work, the technological incubator held a business brunch for the graduation of its first companies: E-ComBr Soluções em Tecnologia and Voss Comunicação.

In 2009, the incubator was transferred to the University Campus, reaffirming its commitment to academia and the support to the development of innovative research. It contributed to the development of the creation project of the Science and Technology Park Chapecó@ and supported the holding of the first edition of SINAPSE da Inovação - a program of the State Government for the support and financing of Startups.

2010 was marked by various activities and achievements for the incubator. Initially it was contemplated, along with the other incubators in the Roda da Inovação network, by the Gene Institute of Blumenau, through the incentive notice PNI/FINEP, acquiring through this more than R\$ 100 thousand BRL to fund its activities for the development of innovative enterprises. In the same year, two important partnerships were established. The first one with Embrapa through the Proeta program (Dissemination and Qualification Program), for the incubation of technology-based companies for the pork and poultry agribusiness. The second one with the Oeste-Deatec Technological Pole, for activities and works with technology companies.

Still in 2010 and in partnership with the Regional Development Departments (Secretarias de Desenvolvimento Regional - SDRs), the incubator was included in the public notice of the FAPESC of the State Government of Santa Catarina for the development and deployment of two new incubators in the region, contributing to the socioeconomic growth of the state and encouraging innovation and entrepreneurship.

Concerned with developing improvements in its administration and quality, the incubator initiated the deployment of the Cerne model in 2012, a methodology for the continuous improvement in business incubation processes geared toward the certification of incubators. Resources were raised in this process through the Sebrae/Cerne notice, which allowed the expansion and improvement of the services provided.

In 2013, with the responsibility of promoting and spreading the culture of innovative entrepreneurship, the technological incubator launched the first Innovation Marathon within 
the framework of the university, a contest aimed at academics of the host institution with the proposal of transforming ideas into businesses. The project obtained excellent results and was repeated in the following year.

Currently, its positioning is still focused on the promotion and structuring of companies involved in the incubation program. Halfway 2016, when this study was conducted, 15 companies were going through the incubation process and 8 companies were graduated. It is important to highlight that the University has developed a project for the establishment of the scientific-technological park Chapeco@ since 2008, of which the incubator will also be a part. This park is in its the physical structure construction phase, which is nearing completion. After the conclusion of this work, the incubator under study will have a more favorable physical structure and environment for the development of its incubation activities.

\subsection{Perceptions about the Incubation Process from the Perspective of the Incubated and Graduated Companies}

A questionnaire was applied to identify the outlook of the entrepreneurs on the incubation process and the impacts of the activities developed by the incubator on their business. It was sent to the 22 companies involved (going through the incubation process or already graduated), of which 14 effectively responded, representing a sample of $63 \%$ of the population under study. Of the companies that effectively answered the questionnaire, $57 \%$ are incubated firms and $43 \%$ are already graduated firms.

The incubation process is composed of three phases, after which the company gets its graduation from the incubator, becoming independent. In the Incubator under study, the first stage is called Business Initiation. In this stage, the ideas of the entrepreneurs are supported that don't yet have a spin-off of the defined product, service or process. The second stage is called Pre-incubation, where the ventures are supported in the initial development of the business plan, with a prototype of the developed product, process or service. The last stage comprises the incubation itself. In this stage, the companies have already formally developed their product/service and the implementation and evaluation of the strategic planning of the company is carried out in accordance with its different aspects (management, marketing, finance and innovation). As such, as already mentioned, the venture can be accompanied with expert advice from the planning phase until the consolidation of its activities (Sebrae, 2015).

According to the data collected in this study, $57 \%$ of the companies stated they did not go through all incubation stages. This finding can be explained by the fact that the study contemplated companies that are yet to graduate. The remaining $43 \%$ of the respondents indicated that their business had indeed achieved all stages. These same companies also classified stage 2 (Pre-incubation) and 3 (Incubation) as the most important periods for the formation and development of their company.

According to the study data, $67 \%$ of the incubated companies were enrolled in the incubation program for 1 to 2 years and the remaining 33\% were linked to it for 3 to 4 years. Of the already graduated companies, most were incubated for only two years and have been graduated between 1 and 3 years. According to data extracted from the ANPROTEC website, businesses can stay linked to the incubator for a period of 4 years and a half considering the business initiation, pre-incubation, incubation and graduation stages (ANPROTEC, 2016). 
With respect to the structure of the companies, $43 \%$ of companies participating in the survey had 1 to 3 employees, $29 \%$ had between 4 and 7 employees and $14 \%$ had between 8 and 12 employees. Finally, 14\% of the surveyed businesses didn't have employees and were operated only by the owners. Most companies linked to the incubator are of the IT sector, which is why they don't need a very large work force to develop their products and services.

When the geographical scope of the surveyed businesses is concerned, they were restricted to the following reality regarding the marketing of their products/services: $38 \%$ of companies operated only in western Santa Catarina; $7 \%$ of companies operated throughout the state of Santa Catarina; another 7\% operated throughout the southern region of Brazil; $27 \%$ of the companies operated throughout Brazil and, finally, $21 \%$ of them also operated abroad. Although a significant number of companies concentrated their activities in the regions closer to the incubator (western Santa Catarina, the State of Santa Catarina and southern Brazil), one can still infer that the technological incubator has provided a significant impetus for the development of the region of Chapecó, host city of the incubator, generating companies with operations on a national and international level.

With regard to the perception of the companies on the activities developed by the incubator, $57 \%$ of respondents mentioned that they totally agree about the effective use in their business of the received training courses and consultancy services. The other $43 \%$, somewhat agree with this statement. In reference to the fact if being included in an incubation program has significantly changed the business' insertion in the market, 50\% responded that they somewhat agree with this proposition, $36 \%$ said they totally agree, $7 \%$ partially disagree and $7 \%$ totally disagree.

From the same perspective, when asked if they would recommend the participation in the incubation process to other startups, $86 \%$ of respondents said they totally agree with the statement and $14 \%$ agreed in part. As for the statement of the possibility of opening their own business even without the support of the incubator, $43 \%$ reported that they totally agreed, $43 \%$ somewhat agreed and $14 \%$ disagreed entirely or partially, revealing that they could only achieve success in their business by being linked to a technological incubator. As can be seen, therefore, most surveyed companies consider the benefits of the incubation process to be important for their development.

In relation to the expectations of participants at the time of entry into the incubation program, the participants mentioned mostly that they were attracted by the opportunity of having a basic infrastructure at their disposal; by the possibility of being constantly supported by specialized professionals and trained in various area of knowledge, in addition to the ease of building a network. In addition, they mentioned other expectations, such as the frequent offering of trainings, the promotion of the company, the conducive environment for growth and the inclusion of innovation in their business, the inclusion in the market and the technicalscientific development of the company.

Still regarding the expectations, $64 \%$ of respondents felt that their initial expectations were met. In another study by Engelman, Fracasso and Brasil (2011) on the quality of services offered by an incubator from the perspective of their own employees and incubated companies, the incubated companies showed interest in knowing the experience of other (incubated) companies through the various available instruments. From the same perspective, the 
employees of the incubator noticed in their day-to-day activities that the incubated companies show great interest in keeping communication channels open for the interaction with other business experiences. They also realized that the specific needs of each incubated company were often not sufficiently known. In addition, these expectations could vary over time, making it difficult for the incubator to plan and offer specific services, or to adjust them to the specific needs of each segment of the incubated companies. The study concluded, therefore, that a careful and constant tracking by the responsible technicians in the incubated companies was important, which also seems to be true for this study.

Business incubators have different organizational models. These models consist of a support, aid and promotion mechanism of the business entities, offering advantages and facilities for the consolidation and promotion of business inside and outside of their structures (Sousa \& Beuren, 2012). In Chart 1, the main activities/services offered by the incubator are displayed in accordance with the preference of the incubated companies.

Chart 1: Main services offered by the incubator according to the perception of the incubated companies

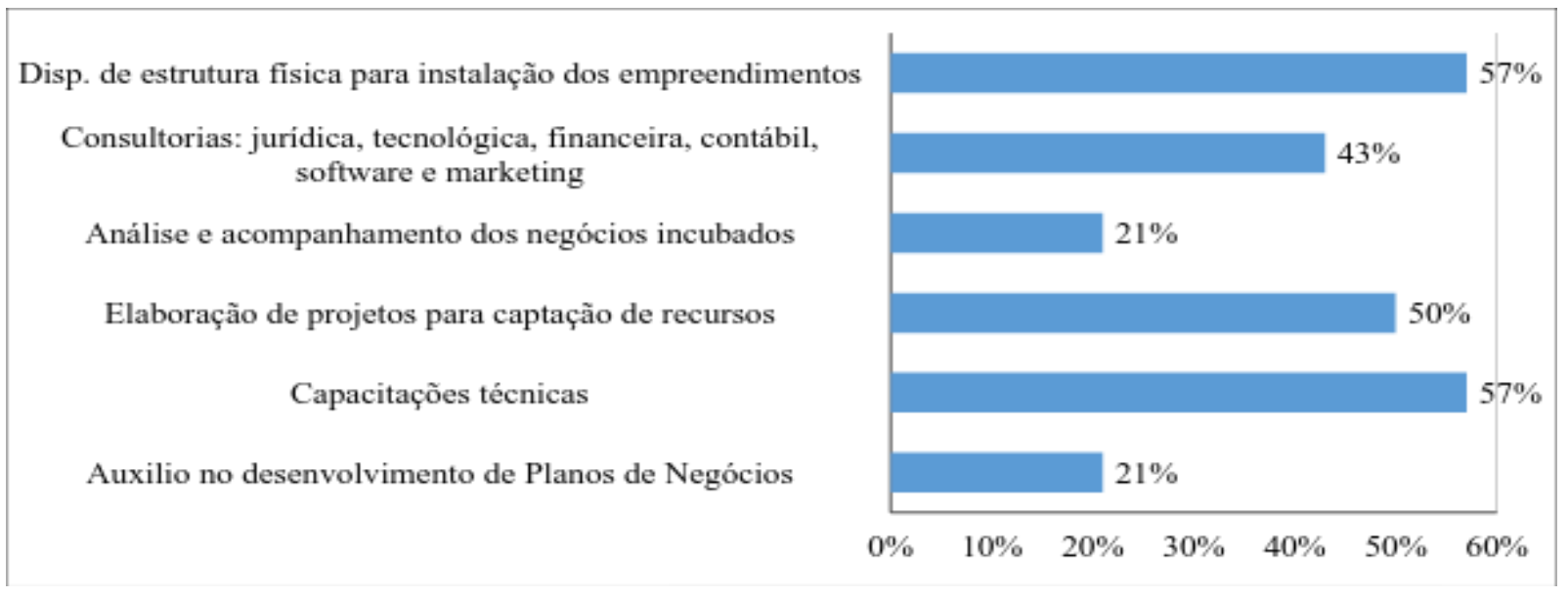

Source: Survey data.

As can be seen in the chart, the most relevant services offered by the incubator for businesses according to the research participants are the provision of a physical structure for establishment of the companies; the technical trainings; the support in the development of fund raising projects; and the legal, technological, financial, accounting, software and marketing consulting services (Unochapecó, 2016).

Chart 2 presents the main advantages or benefits that companies gain by being included in an incubation program from the perspective of the incubated companies. 
Chart 2: The main advantages or benefits of incubation from the perspective of the incubated companies

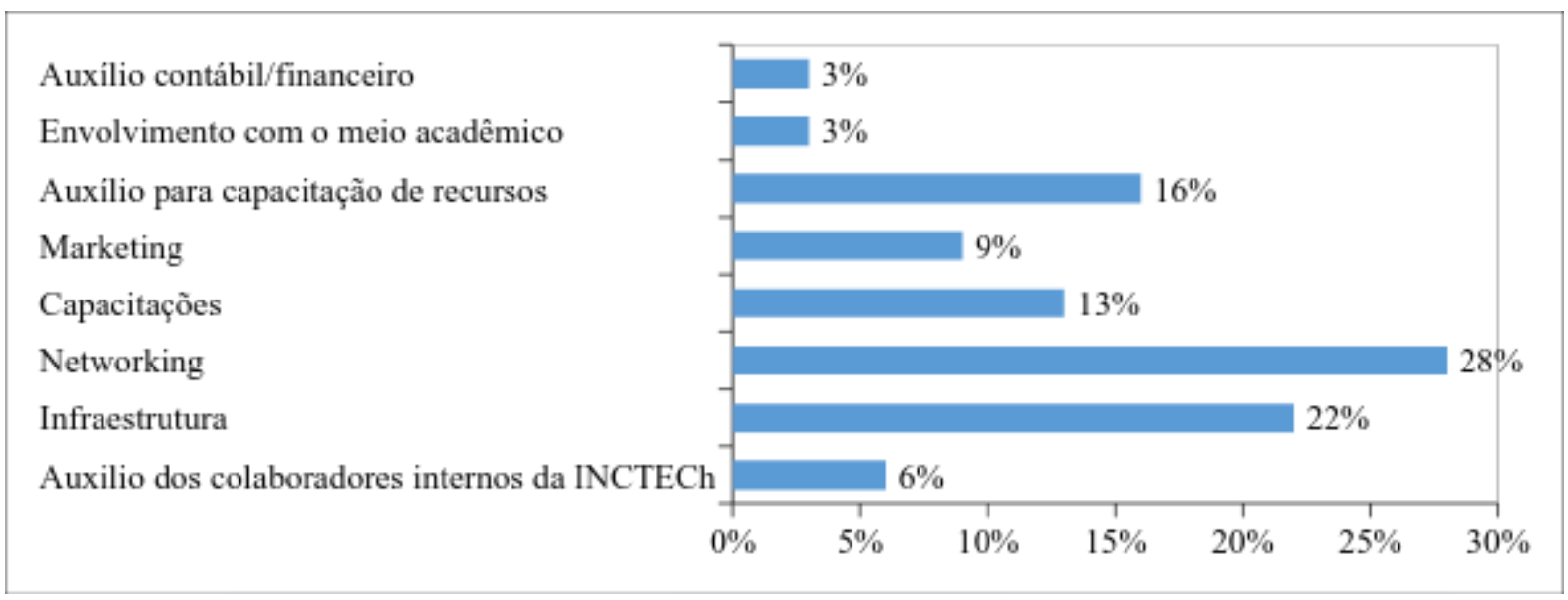

Source: Survey data.

As can be seen, these data confirm the previous information, since, from the point of view of survey participants, the main benefits offered by the incubator are the possibility of building a network, the availability of an infrastructure, and the support in the raising of resources.

These data are in line with those obtained in other studies. According to a study conducted by Sousa and Beuren (2012) in the incubator MIDI Tecnológico (Microdistrito Industrial de Base Tecnológica), the main services offered by the incubator, in the perception of its users, are the material and administrative infrastructure, which are fundamental reasons that led the entrepreneurs to seek this incubator in order to set up and implement their projects.

Regarding the possibility of building a network as one of the main advantages and benefits, the same view was also observed in a study conducted by Fiates et al. (2013), whose data confirmed that an incubator favors the formation of relationship networks that stimulate innovation and interaction with other actors, which may foster the internationalization process.

The incubator under study has developed its activities since 2001, and at the beginning of its operations, its methodology didn't adhere to the current standard. This fact was felt by the already graduated respondents, who mentioned that, at that time, the difficulties encountered in the incubation process were: the lack of an effective possibility to form a network, the slowness in the process and the excessive bureaucracy, the reduced possibilities of sharing experiences and the fragility of the methodology used at the time, which didn't fully meet the needs of the incubated companies. To a significant extent, these factors were remedied in the current incubation process developed by the Incubator, which is attested by the low number of citations concerning the perceived difficulties by the current incubated companies. Even so, some references were still made concerning the difficulties with the small physical space available and with the lack of more effective support in the HR, Marketing, Legal Consulting and Sales Process Structuring. 
When they enter into an incubation program, companies start experiencing a varied environment, guided by a methodology that seeks to strengthen and consolidate their business, through services, initiatives and opportunities the company probably wouldn't be able to access outside the incubation process. The constant participation in trade fairs and events for the promotion of the business is one of these opportunities. Among the participants of the survey, $64 \%$ of respondents mentioned the participation in this type of activity. Another opportunity accessible to the incubated companies, is the possibility of obtaining recognition and awards in the academic and business environment. In all, 57\% of respondents claimed to have received this type of recognition or award after entering the incubation program. In addition, companies are encouraged to develop new products and services linked to their line of business in the incubation program. This is so the incubation maintains its focus precisely on the innovation process. The data collected in the survey reveals that this is perhaps one of the most effective advantages for the incubated businesses in the case under study, since $100 \%$ of survey participants reported having developed new products and services throughout the process.

Finally, some improvements were identified when the surveyed companies were questioned regarding possible suggestions for the improvement of the incubation program. Most suggestions were geared toward increasing the enforcement of the commitment of employees in relation to the incubated companies, thus making them more present in the management of the businesses deployed in the incubator. Another point raised was the need for intensifying the company acceleration process, making it more appropriate with more current techniques and focusing on the startup mentality through a shorter, but more systematic process.

\section{CONCLUSIONS AND RECOMMENDATIONS OF THE STUDY}

The objective of this study was to analyze the importance of the incubation activities in making the development of incubated and/or graduated micro and small enterprises viable. In this sense, the authors believe that the research objective was met, since, as can be seen in the charts and results presented in the previous sections, the perspective of the incubated and graduated companies could be analyzed in relation to the activities carried out during the incubation process.

With respect to the results of the study, $67 \%$ of the incubated companies were enrolled between 1 and 2 years in the incubation program and the remaining 33\% were linked to it for 3 to 4 years. Of the already graduated companies, most were incubated for only two years and have been graduated between 1 and 3 years. When the structure of the companies is concerned, $43 \%$ of participants in the survey had 1 to 3 employees, $29 \%$ had between 4 and 7 employees and $14 \%$ had between 8 and 12 employees.

With respect to the geographic scope of the surveyed companies in the marketing of their products, $38 \%$ operated only in western Santa Catarina and 62\% operated in other regions, from the state of Santa Catarina (7\%), the southern region (7\%) and Brazil (27\%) to even other countries (21\%), which points to the importance of the incubator for the development of the region in which it is located. A large part of the respondents mentioned that they totally agree about the effective use in their business of the received training courses and consultancy services. From the same perspective, when asked if they would recommend the participation 
in the incubation process to other startups, $86 \%$ of respondents said they totally agree with the statement.

In relation to the expectations of the participants at the time of entry into the incubation program, the participants mentioned that they were attracted mainly by the availability of the physical structure for the establishment of the companies; by the possibility of accessing technical trainings; by the support in the development of fund raising projects; and by the possibility of having access to consulting in the legal, technological, financial, accounting, software and marketing areas. The main advantages or benefits gained by the companies included in an incubation program from the perspective of the survey participants include: the possibility of building a network, the availability of an infrastructure and the assistance in the raising of resources.

In the incubation program, companies start coexisting in a special environment, guided by a methodology that seeks to strengthen and consolidate them. According to the respondents, the constant participation in trade fairs and events for the promotion of the business is one of these opportunities. Another opportunity accessible to the incubated companies is the possibility of obtaining recognition and awards in the academic and business environment. In addition, companies are encouraged to develop new products and services linked to their line of business in the incubation program.

The presented data allows for the conclusion that the incubation plays an important role in the development of the incubated companies, providing opportunities and support to entrepreneurs for their survival in the market. It stimulates the development of the businesses through a favorable environment to put their economic activities into practice, providing infrastructure, management support, technical trainings, and assistance in the raising of financial resources, among other support tools.

Some of the limitations of the incubation process that were listed in the survey might be explained by the fact that the participating companies were incubated at different moments in the trajectory of the incubator. There has been a remarkable improvement in the incubation process and the techniques employed by the incubator under study along its trajectory. This means differences can be observed in the perception of the participants in accordance with the period in which they took part in the incubation process. The recorded problems related to restrictions for the establishment of a network, the slow processes and excessive bureaucracy, were perceived only among the incubated companies who participated in the process in the first years of the incubator's operation.

Finally, a separate study of the graduated and incubated companies is suggested as future research. This will allow a comparison between the perception of companies according to the different periods of the incubator's trajectory because the incubation process has been transformed and improved over time, which can generate different perceptions about the process. The continuation of this study involving the other incubators linked to universities in the state of Santa Catarina is also recommended, so as to compare the incubators and investigate their role in the economic development of the state. 


\section{REFERENCES}

Aguiar, A. V. C. de. (2000). A transferência de informação tecnológica entre a Universidade Federal da Paraíba e as empresas de base tecnológica do pólo tecnológico de Campina Grade.

Dissertação de Mestrado, Universidade Federal de Paraíba, João Pessoa, PB, Brasil.

ANPROTEC - Associação Nacional de Entidades Promotoras de Empreendimentos Inovadores. Incubadoras e Parques. (2011). Available at: <http://www.anprotec.org.br >. Accessed on: 07 set. 2016.

Aranha, J. A. (2000). Incubadoras de empresas. In: Filion, L. J. \& Dolabela, F. Boa idéia! E agora? São Paulo: Cultura Editores Associados. cap. 17.

Audy, J. \& Morosini, M. (2008). Inovação e qualidade na universidade. Porto Alegre: EDIPUCRS, p.495-525.

Benedetti, M. H. \& Torkomian, A. L. V. (2011). Uma análise da influência da cooperação Universidade-Empresa sobre a inovação tecnológica. Gestão e Produção, 18 (1), 145- 158.

Bonacorsi, A. \& Piccaluga, A. (1994). A theoretical framework for the evaluation of universityindustry relationships. $R \& D$ Management, 24 (3), $229-247$.

Brasil. (2002). Ministério da Ciência e Tecnologia. Livro branco: ciência, tecnologia e inovação. Brasília: Ministério da Ciência e Tecnologia.

Brisolla, S., Corder, S., Gomes, E., \& Mello, D. (1997). As relações universidade-empresa-governo: Um estudo sobre a Universidade Estadual de Campinas (Unicamp). Educação \& sociedade, 18(61), 187-209.

Castro, P. G., da Silva Teixeira, A. L., \& de Lima, J. E. (2014). A relação entre os canais de transferência de conhecimento das Universidades/IPPS e o desempenho inovativo das firmas no Brasil. Revista Brasileira de Inovação, $13(2$ jul/dez), 345-370.

Clark, B.R. (2004). Delineating the Character of the Entrepreneurial University. Higher Education Policy, 17 (1), 355-370.

D’Afonsêca, L. A. G. G. (2007). O perfil e o comportamento estratégico dos empreendedores de empresas incubadas em Salvador. 2007. 104 f. Dissertação de Mestrado em Administração, Universidade de Salvador - UNIFACS, Salvador, BA, Brasil.

Dornelas, J. C. A. (2002). Planejando incubadoras de empresas: como desenvolver um plano de negócios para incubadoras. Rio de Janeiro: Campus.

Etzkowitz, H. (2009). Hélice tríplice: Universidade - Indústria - Governo, inovação em movimento. Porto Alegre: EDIPUCRS.

Fiates, G. G. S., Martins, C., Fiates, J. E. A., Martignago, G., \& Santos, N. D. (2013). Análise do papel da incubadora na internacionalização de empresas de base tecnológica, incubadas e graduadas. Revista Eletrônica de Estratégia \& Negócios, 6(1), 252-274.

da Gama Mota, T. L. N. (2013). Interação universidade-empresa na sociedade do conhecimento: reflexões e realidade. Ciência da Informação, 28(1).

Garnica, L. A., \& Torkomian, A. L. V. (2009). Gestão de tecnologia em universidades: uma análise do patenteamento e dos fatores de dificuldade e de apoio à transferência de tecnologia no Estado de São Paulo. Gestão \& Produção, 16(4), 624-638.

Geuna, A. \& Muscio, A. (2009). The Governance of University Knowledge Transfer: A critical review of the Literature. Minerva, 47(1), 93-114. 
Gevaerd, E. C. (2005). A importância da incubadora de base tecnológica celta para o desenvolvimento da microrregião de Florianópolis (Doctoral dissertation, Dissertação de Mestrado, Centro de Ciências Humanas e da Comunicação, Universidade Regional de Blumenau, Florianópolis).

Gil, A. C. (2010). Métodos e Técnicas de Pesquisa Social (6ª ed.). São Paulo: Atlas.

Joseph, K. J. \& Abraham, V. (2009). University-industry interactions and innovation in India: patterns, determinants, and effects in select industries. Seoul Journal of Economics, 22 (4), 467498.

Levy, R., Roux, P. \& Wolff, S. (2000). An analysis of science-industry collaborative patterns in large EuropeanUniversity. Journal of Technology Transfer, 25 (1), 111-133.

Marcovitch, J. A. (1999). Cooperação da universidade moderna com o setor empresarial. RAUSP Revista de Administração, São Paulo, 34 (4), 13-17.

Maya, D.R. (2008). El Processo de transferencia de tecnologia. Gestión Tecnológica: conceptos y prácticas, México: PyV.

Meyer, M., Grant, K., Morlacchi, P. \& Weckowska, D. (2014). Triple Helix indicators as an emergent area of enquiry: A bibliometric perspective. Scientometrics, 99 (1), 151- 174.

Mussi, C. C., Faraco, R., Angeloni, M. T., \& Peres, F. M. (2013). Rede social para transferência de conhecimento e inovação social. Revista Pensamento Contemporâneo em Administração, 7(4), 77 97.

Rodrigues, L.C. \& Tontini, G. (1997). A universidade empreendedora: geração e transferência de tecnologia como fator agregador. Revista de Negócios da FURB, 2 (1), 37-39.

Sebrae. (2015). Glossário dinâmico de termos na área de Tecnópolis, Parques tecnológicos e Incubadoras de empresas. Brasília: Associação Nacional das Entidades Promotoras de Empreendimentos de Tecnologias Avançadas.

Silva, C. V. (2010). Processo de transferência de conhecimento na interação universidade-empresa: programas de incubação do distrito federal. Dissertação de Mestrado, Curso de Pós-Graduação em Ciência da Informação, Universidade de Brasília, Brasília, DF, Brasil.

Silva, F. M. G., \& Andrade Júnior, P. P. (2012). Incubadoras de empresas e o desenvolvimento econômico e tecnológico. Revista de Engenharia e Tecnologia, 4(3): 44.

Soria, A. F. (2011). Gestão da transferência de tecnologia na interação universidade-empresa. Dissertação de Mestrado, Programa de Mestrado em Administração e Negócios da Faculdade de Administração, Contabilidade e Economia, Pontifícia Universidade Católica do Rio Grande do Sul, Porto Alegre, RS, Brasil.

Sousa, M. A. B., \& Beuren, I. M. (2012). Expectativas percebidas pelos empreendedores no processo de incubação. GESTÃO.Org - Revista Eletrônica de Gestão Organizacional, 10(1), 1-27.

Stainsack, C. (2003). Estruturação, organização, e gestão de incubadoras tecnológica. Dissertação de Mestrado, Programa de Mestrado em Tecnologia, Centro Federal de Educação Tecnológico do Paraná, Curitiba, PR, Brasil.

Turato, E. R. (2003). Tratado da metodologia da pesquisa clínico-qualitativa: construção teóricoepistemológica, discussão comparada e aplicação nas áreas da saúde e humanas (2 ${ }^{\mathrm{a}} \mathrm{ed}$.). Petrópolis: Vozes.

Unochapecó. (2013). Objetivos da Incubadora Tecnológica. Available at: <https://www.unochapeco.edu.br/inctech/info/objetivos-20>. Accessed on: 05 set. 2016. 